Anton Bierl

\title{
Myth and the Novel: Introductory Remarks and Comments on the Roundtable Discussion
}

\section{Introduction}

In the last two decades we can notice a new interest in myth and ritual, especially in Greek Studies. Both categories interact with plot and literature. We can even speak about mythical and ritual poetics in Greek literature from its earliest beginnings until Imperial times. ${ }^{1}$ In the genre of the novel myths have been rather understudied, even though they appear ubiquitously in the texts. ${ }^{2}$ Therefore, I had the idea of organizing a roundtable at ICAN IV with the title 'Myth and the Ancient Novel' together with Marília Futre Pinheiro, who had just published a volume on Greek myth (2011). ${ }^{3}$

We agreed on the following lead questions: How does myth influence and shape the plot of the novel? Are there similarities in the mode of narration between myth and novel? How can an episode be marked by superimposing certain myths? What is the specific mythic poetics of the novel? Can we talk about a mythopoeia in the novel? Which myths are utilized in particular and emphasized, and what might be the reason? Our approach, as becomes clear, is far from a search for origins in the sense of a development from myth to novel. Thus, myth is not, as Karl Kerényi believed, the origin or Urbild of the genre from where, in accordance with the trend of a literary secularization, the novel developed into a bourgeois (verbürgerlichte) and humanized form. ${ }^{4}$ Therefore, the chain of suffering and erotic episodes can hardly be localized in a single Egyptian myth of Isis and Osiris; rather, myth has to be seen as a poetic, narrative and aesthetic device. By using the communicative medium of myth, fundamental problems that concern all human beings can be investigated in various ways. Thus, the novel is not deriva-

1 See Bierl 2002; 2007a; previously Bierl 2001 (Engl. 2009); for the concept of 'ritual poetics', see Yatromanolakis and Roilos 2003; 2004.

2 Recent exceptions are Cueva 2004 and Bierl 2007b. See earlier e.g. Laplace 1983; MacQueen 1990.

3 Lisbon, 21 July 2008, 8 to 10 p.m. (chair: Anton Bierl).

4 Urbild: Kerényi 1962², 43; see 'Hellenisierung - Humanisierung' (ibid. 263) and the Nachbetrachtungen of the second edition ('Nachwort über die Methode', esp. 291 n. 2); see also Henrichs 2006. 
tive of myth but rather functions in conjunction with myth as an effective aesthetic and poetic medium. As I have shown in my previous work, anthropological concepts and critical phases, including the transition of puberty and early marriage, can be emphasized and fictionally staged in such a mythical discourse. Myth is the authoritative word which possesses exemplary significance and, simultaneously, can focus on normative behavior ex negativo by processing transgressive scenarios. Like mythical tales and images, the novel is able to model and legitimize roles and thinking patterns. On the one hand, myth puts events in an ideal frame; on the other hand, the inherent tension of oppositions turns into violence, chaos and transgression. Moreover, through myth and novels, one can project imaginary worlds, scan and act out wishes and fears, and delineate the power of Eros.

As I have shown, myth is linked to the basic structure of the novel as an initiation story or rite de passage. ${ }^{5}$ Furthermore, myth is related to the production of the novel as a narrative, contributes to education and paideia, and is a feature of the local embedding and sophistication of the author. It is part of an intertextual and interdiscursive play which conforms to the taste and expectations of the readers. Moreover, myth - in Burkert's $(1979,23)$ words, 'a traditional tale with secondary, partial reference to something of collective importance' - is simply 'good to think with'. Last but not least, $\mu \tilde{v} \theta$ os has already been applied to the plot, in particular to tragedy (e.g. Arist. Po. 1450a4-5), and has consequently been used as a terminus technicus for plot in all fictional literature. ${ }^{6}$

\section{Results}

After an exhausting first conference day, our roundtable tried to involve the audience on a hot summer evening. The result of our thoughts and lively discussions can be summarized as following: myth plays a significant role in the plots of the novels; it triggers the action at decisive points (often by means of an ekphrasis), produces important analogies, intensifies content through exempla, and is simply material that is 'good to think and play with' (Cueva and Graf). Sometimes, the novel can be understood as a reaction to a mythical narration (Graf). Rare myths, moreover, can serve as signs of sophistic education (Bremmer), and local myths play a particular role in that paideia, even seen as the foil of 'glocalization' (Whitmarsh). In the literary form, myth becomes part of an overall intertextual

5 Bierl 2007b.

6 Kerényi 1962², 1-23. 
play (Cueva). However, myth is not only read, but also performed and part of an interperformative, interdiscursive and interritual process as well. Furthermore, through myths one can express hope for union with the divine (Zimmerman). Moreover, we should not forget that myths place emphasis on gender, violence and power (Futre Pinheiro). In the discussion, Fritz Graf made the important point that novels were the new myths of the Greeks. I tried to expand on this interesting point with a contribution to the role of myth in Longus. ${ }^{7}$

\section{Novel as Myth and Dream}

Before I come to Longus, I want to elaborate on some thoughts about how all ideal love novels might be considered new myths, or reactions to myths as translations into their own fictitious world. Both young protagonists are of the highest social status, beautiful and brilliant, and far above human standards in all respects. Accordingly, they behave and act as if they were heroic or even divine. All in all, they are like superstars, comparable to the movie heroes of Hollywood, or even better, Bollywood. The young people's beauty is simply outstanding. Therefore it goes without saying that third parties fall in love with them as soon as they see them. Moreover, they are explicitly compared to glamorous figures of myth, to famous young heroes and heroines, familiar from tragedy (or even to gods and statues). Thus, as Graf notes, 'the borderline between mortals and gods in the novel sometimes seems unstable.' Therefore, our stars frequently appear to others in epiphany-like scenes and seem to be gods. Thus, they are often mistaken for gods or equated with them. ${ }^{8}$ Through further exempla, models and analogies, a simple love story can assume the flair of the sublime and highlight key themes. ${ }^{9}$ The mythic coloring is not deployed at random; rather, the protagonists are notoriously compared with heroic figures who personify the girl or the boy on the threshold of adulthood. Or they are often assimilated to gods responsible for this decisive rite de passage. Accordingly, on the male side, novelists tend to use figures like Hippolytus, Achilles, Orestes and Apollo, and on the female side, Iphigenia, Andromeda, Philomela, Artemis and Aphrodite, among others. At the same time, the accompanying myths often reflect Burkert's 'maiden's tragedy'. ${ }^{10}$ As I have outlined elsewhere, the love novel thematizes, acts out

7 Bierl 2009.

8 Hägg 2002; Schmeling 2005; Bierl 2007b, 288-298.

9 Cueva 2004.

10 See Burkert 1979, 6-7; Burkert 1996, 69-79. For the novel, see e.g. Ach. Tat. 3,15-22. 
and resonates with this fundamental crisis of transition. ${ }^{11}$ It is well known that the protagonists are very young and in the middle of puberty. Their sudden experience of love runs parallel to the discovery of sexuality. Moreover, the novel's oneiric perspective is a feature of the myth-like plot, because myth and dream are intertwined. Synesius (De insomniis 19,45-53) believes that myths and fantastic stories are based on dreams. Therefore, he thinks that sophists should complement their rhetoric progymnasmata, which are full of mythological examples, with dream narrations. It is a well-known fact that such mythological exercises of oratory have a considerable influence on the narrative patterns and technique of the novelists. Thus, novels are often associated with myths pretending to be logoi. $^{12}$

\section{The Novel as the New Myth: Longus}

Taking Pan's remark that the Methymneans have 'snatched from the altars a girl whom Eros wants to make a myth', that is, the subject of a novelistic story

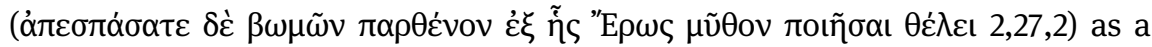
point of departure, ${ }^{13}$ I attempted to show how Daphnis and Chloe is composed entirely as a myth. ${ }^{14}$ Longus uses several strategies of renaturalization and remythization to build up the mythic and ideal dimension of his novel. The artful mimesis of how a young boy and girl take four entire books in order to learn to make love is most amusing, and the regression to the perspective of children creates pleasure. ${ }^{15}$ In early modern scholarship, myth was sometimes associated with the childhood phase of human evolution. ${ }^{16}$ Upon closer inspection, however, the idyllic novel is only the simulation and artificial mimesis of a myth. For sophists like Longus, the gods acting naturally in the bucolic landscape are no longer real, religious beings, but rather secularized gods of literature. In an intertextual play, they belong instead to literary pretexts and mythology. The author tries to lull the reader through this mythic world. As readers, we should be aware of Longus' deceptive strategies. He deploys the gods - artificial products of

11 Bierl 2007b, esp. 262-276. From a different perspective, see Lalanne 2006.

12 Cf. Ach. Tat. 1,2,1-2; Chariton 4,2,13; 5,8,2; 6,3,6; Long. 2,7,1; 2,27,2; 4,20,1. See Pizzone in this volume. On the oneiric in Xen. Eph., see Bierl 2006.

13 See also Morgan 1994, 75-77.

14 Bierl 2009.

15 According to Aristotle, men like to imitate from childhood onward, and mimesis provides pleasure (Arist. Po. 1448b4-12).

16 Graf $1991^{3}$, e.g. 15, 20, 32. 
his literary inventio - to create his plasmatic mythos, and he self-consciously uses this theoretical and metaliterary term for plot in a fictional story. ${ }^{17}$ In the aetiological Ur-mythos of how men learn to make love for the first time, gods are both the principles and first movers. After all, Longus purposefully oscillates between myth and mythology. He uses myth to create the atmosphere of natural origins as the basis of his plot. At the same time, however, he refers to the artificiality of his aesthetic construct through open breaches and ironic comments.

\section{Positions and Comments}

Jan Bremmer opens his contribution with the critical remark that I overemphasize the connection with Volksgut, popular fairy tales, and overlook the context of handbook sophistry and the use of myth as demonstration of abstruse education. I want to clarify my position: I refer, of course, to such a popular and performative substrate, but I am well aware that myth is part of the sophistic culture and used as a showcase of erudition. Bremmer's emphasis on paideia is well taken and obvious, and I share his view, as I have just shown above. However, we have to ask which myths the authors prefer, along with why and how they use them. Moreover, even if the novelists take them without a doubt from literary sources, I am convinced it is important to initiate thoughts on the function of these applied myths for the plot in the specific context of the genre. In such a perspective, it is perfectly legitimate to examine the basis of narration in popular culture. Märchen and popular traditions are the key to research on the function of such stories. It is my conviction that making observations about where a myth comes from, in the sense of Quellenforschung, is insufficient. Rather, it is essential to initiate an investigation into the deeper narratological, discursive and psycho-historical structure of the myths dealing with the crisis of puberty and premature marriage. Margaret Alexiou's book After Antiquity. Greek Language, Myth, and Metaphor (2002) had a decisive influence on my fresh look at myth. According to her, ${ }^{18}$ the meaning of myth is not a universal, but lies in the gap between true and false, between past and present, and is permanently deferred in a dialogic process. Myth, therefore, is not unidirectional, but multidimensional, dynamic, and in constant transformation. Therefore, myth can help to highlight, reflect and act

17 Arist. Po. 1450a4-5; on the ancient 'theory' of the novel, see Kerényi 1962², 1-23, on $\mu \tilde{v} \theta$ oเ ibid. 13.

18 See Alexiou 2002, 151-171. 
out a fundamental crisis, such as puberty and early marriage represent, and it can be linked to literature as well. I wonder why Bremmer, a scholar who has worked so much with the paradigm of initiation and with Burkert's concepts, has a problem with following me on this hermeneutical path. To repeat, I believe that behind the novelistic plots and traditional tales we can detect a psycho-anthropological substrate. It is the 'maiden's [and/or boy's] tragedy', but less in the sense of Walter Burkert, who tries to establish a structural program of action in biological terms, ${ }^{19}$ than as a loose set of narrative motifs which can be freely associated in various combinations. Love as nosos is constitutive of the love novel. The desire of the young couple for each other, the sense of 'absence', 20 gives way to miraculous fantasies of loss, fear, sexual threats by third parties, death and rebirth; they are transformed into stories of separation, sacrifice, rape and violence, on the level of myth, fairy-tale and novelistic literature. In a Lacanian sense, the deep longing leads to a gliding concatenation of signifiers in a metaphorical and metonymical process. ${ }^{21}$

Edmund Cueva's paper is a precise summary of his useful monograph The Myths of Fiction. Studies in the Canonical Greek Novels (2004). I agree with his intertextual and narratological perspective which analyzes character illustration using analogies and myth as a plot-structuring device. However, I still miss, to some extent, more detailed analyses of the textual structure. Moreover, he could apply a more refined theoretical approach to understanding how myth and ritual function in a mytho-ritual poetics. We still have to ask why and how the novelists use the particular myths in their intertextual play on canonical authors.

On a remarkable theoretical level, Marilia Futre Pinheiro explores the role of myth as an analogy to the fictional character of the protagonists in terms of gender role, violence and power relations. She rightly rejects older feminist research that saw the woman always as the Other and emphasizes instead that the gender categories stressed by mythic parallels work in a dialogic, unstable, dangerously oscillating, ambiguous and dynamic manner. Thus, men can transgress on the feminine side and women on the male one. Therefore, the novel, particularly with the comic, ironic model of Achilles Tatius, incessantly glides along the traditional gender norms, subverting and affirming them simultaneously.

At the same time, Futre Pinheiro calls into question the Foucauldian paradigm and Konstan's (1994) widely accepted theory of a 'sexual symmetry'. Obviously

19 Burkert 1996, 69-79 (on the model of Psyche in Apul. Met.).

20 Barthes 1979, 13-17.

21 Lacan 1966, 260. See Bierl 2006, esp. 85-86; 2007, 244-245; and Bierl in this volume. 
women in the novel are different, sometimes even stronger than men and thus, on a surface level, ideologically equal, but, as I try to work out myself in an article on sacrifice in Achilles Tatius, ${ }^{22}$ the female body is constantly subject to the male gaze and fantasies of violence, rape, torture and abuse.

Thus, as Futre Pinheiro rightly argues, women displayed in such a perspective are still being shaped according to the social norms and values of a patriarchal society. But they can find their own voice in silent resistance, as underlined by ecphrastically focused mythic analogies, such as in the case of Philomela's myth in Achilles Tatius $(5,5)$, or in many other instances.

Besides all the tendencies of subversion, irreverence and transgression, I would add that the traditional power and gender relation finally prevails. Moreover, it is crucial to the ancient romance that the display of violence on the chaste and intact female body is also part of the sexual aggression by third parties expressed in metonymic and metaphorical variations. Such an erotic poetics, constantly highlighted through mythic and ritual analogies, is constitutive of the genre as love novel.

I have already expressed my appreciation for Fritz Graf's paper above. He investigates the cognitive and narratological aspects of myths in the novel, and thus responds to the decisive question of how myth functions in the novel. It is not only a showcase of paideia, 'a learned arabesque', but also a device for successfully telling a story. Like Whitmarsh, he tackles old theories of possible origins in a new way. Coming back to Erwin Rohde, Graf does not view the link to myth in an evolutionary sense, but instead tries to explain myth in novel as a 'reaction to mythic narrations' and as a phenomenon of reception and translation into new generic contexts.

Tim Whitmarsh revisits Bruno Lavagnini and his idea of how local myths could serve as a possible source for the novel. He is well aware that no local saga can really be called a novel. However, he shows how epichoric myth is constituent of the intertextual web, using Lesbos and its traditions in Longus as an example, and he tackles the problem of how it can be authentic or a literary commonplace, applying a sophisticated theoretical approach of framing, since Longus' literary world, after all, is a Panhellenic construct.

Maaike Zimmerman describes the mythical dimension of Apuleius with special reference to the mythical undercurrent of Dionysus. She shows how the important motif, the hope of union with the divine, is implicitly linked to Dionysus, the god of mysteries and concern with life after death. Zimmerman's reading demonstrates the capricious and manifold web of allusions and associations that

22 Bierl 2012. 
are too diffuse to be locked into a unidirectional pattern of Isis and Osiris. She recalls that Merkelbach had tried to confine the sense of Metamorphoses to such a theoretical bed of Procrustes. In some ways, however, she follows Merkelbach (1988) in his approach to Longus. We might ask whether Dionysus might symbolize even more than afterlife and mysteries. I think of comic inversions, the idea of metamorphosis, wine, sexuality, phallus, violence, sacrifice and cruel sparagmos, theater, festival, spectacular performances in the arena, and even metapoetic self-consciousness.

Let us take a look at Lucius' bald head $(11,30,5)$ as an example. His baldness stands in sharp contrast to the emphasis on hair and sexual attractiveness in the novel. Being hairless is a common feature of comic inversion. Lucius is finally initiated into mysteries of Osiris, a god associated with Dionysus, and he envisions thyrsoi and ivy. In the realm of Dionysus, we meet his escort of satyrs with their notorious baldness. They are linked with ithyphallic erections, a sign of sexual hyperactivity that fails to come to terms with the opposite sex. Lucius was transformed into an ass, an animal that is also part of Dionysus' foolish entourage, and then back into his human form. At the very end, he experiences new transformations in the form of mystery initiations. Yet even at this point he retains some signs of his former existence: he is naive, gullible and overcredulous; he is curious and full of craving for the miraculous and the transcendent.

\section{Final Remark}

All in all, the participants and listeners left enriched by the new perspectives that our roundtable gave to very old questions. And simply given the fact that we brought - along with all recent theoretical insights - myth as the constituent element of the plot of the novels to the scholarly attention of a large number of specialists, our roundtable was, I hope, a success.

\section{Bibliography}

Alexiou, M. 2002. After Antiquity. Greek Language, Myth, and Metaphor, Ithaca and London: Cornell University Press.

Barthes, R. 1979. A Lover's Discourse. Fragments (translated by R. Howard), London: Hill and Wang.

Bierl, A. 2001. Der Chor in der Alten Komödie. Ritual und Performativität, Munich and Leipzig: Saur (see the revised second English edition Bierl 2009). 
Bierl, A. 2002. 'Religion und Literatur', DNP15/2, 669-677.

Bierl, A. 2006. 'Räume im Anderen und der griechische Liebesroman des Xenophon von Ephesos. Träume?', in: A. Loprieno (ed.), Mensch und Raum von der Antike bis zur Gegenwart, Munich and Leipzig: Saur. 71-103.

Bierl, A. 2007a. 'Literatur und Religion als Rito- und Mythopoetik. Überblicksartikel zu einem neuen Ansatz in der Klassischen Philologie', in: A. Bierl, R. Lämmle and K. Wesselmann (eds.), Literatur und Religion I. Wege zu einer mythisch-rituellen Poetik bei den Griechen, Berlin and New York: de Gruyter. 1-76.

Bierl, A. 2007b. 'Mysterien der Liebe und die Initiation Jugendlicher. Literatur und Religion im griechischen Roman', in: A. Bierl, R. Lämmle and K. Wesselmann (eds.), Literatur und Religion II. Wege zu einer mythisch-rituellen Poetik bei den Griechen, Berlin and New York: de Gruyter. 239-334.

Bierl, A. 2009. Ritual and Performativity. The Chorus in Old Comedy (translated by A. Hollmann), Washington, DC and Cambridge, MA: Harvard University Press.

Bierl, A. 2012. 'Ästhetik, Sex und Opfer: Der Blick auf die hingeschlachtete Jungfrau im Liebesroman des Achilleus Tatios', in: A. Honold, A. Bierl and V. Luppi (eds.), Ästhetik des Opfers. Zeichen/Handlungen in Ritual und Spiel, Munich: Fink. 131-161.

Burkert, W. 1979. Structure and History in Greek Mythology and Ritual, Berkeley et al.: University of California Press.

Burkert, W. 1996. Creation of the Sacred. Tracks of Biology in Early Religions, Cambridge, MA and London: Harvard University Press.

Cueva, E. P. 2004. The Myths of Fiction. Studies in the Canonical Greek Novels, Ann Arbor: University of Michigan Press.

Futre Pinheiro, M. P. 2011. Mitos e Lendas da Grécia Antiga, Lisboa: Clássica Editora (first edition: Lisboa, Livros e Livros, 2007).

Graf, F. 199133. Griechische Mythologie. Eine Einführung, Munich and Zurich: Artemis \& Winkler $\left(1985^{1}\right)$.

Hägg, T. 2002. 'Epiphany in the Greek Novels: The Emplotment of a Metaphor', Eranos 100, 51-61.

Henrichs, A. 2006. 'Der antike Roman: Kerényi und die Folgen', in: R. Schlesier and R. Sanchiño Martínez (eds.), Neuhumanismus und Anthropologie des griechischen Mythos. Karl Kerényi im europäischen Kontext des 20. Jahrhunderts, Locarno: Rezzonico. 57-70.

Kerényi, K. $1962^{2}$. Die griechisch-orientalische Romanliteratur in religionsgeschichtlicher Beleuchtung, Darmstadt: Wissenschaftliche Buchgesellschaft $\left(1927^{1} ; 1973^{3}\right)$.

Lacan, J. 1966. Ecrits I, Paris: Seuil.

Lalanne, S. 2006. Une éducation grecque. Rites de passage et construction des genres dans le roman grec ancien, Paris: La Découverte.

Laplace, M. 1983. 'Légende et fiction chez Achille Tatius: les personnages de Leucippé et de lô', $B A G B, 311-318$.

MacQueen, B. D. 1990. Myth, Rhetoric, and Fiction. A Reading of Longus's Daphnis and Chloe, Lincoln, NB and London: University of Nebraska Press.

Morgan, J. R. 1994. 'Daphnis and Chloe. Love's Own Sweet Story', in: J. R. Morgan and R. Stoneman (eds.), Greek Fiction. The Greek Novel in Context, London and New York: Routledge. 64-79.

Schmeling, G. 2005. 'Callirhoe: God-like Beauty and the Making of a Celebrity', in: S. Harrison, M. Paschalis and S. Frangoulidis (eds.), Metaphor and the Ancient Novel (Ancient Narrative, Suppl. 4), Groningen: Barkhuis and Groningen University Library. 36-49. 
Yatromanolakis, D. and P. Roilos 2003. Towards a Ritual Poetics, Athens: Foundation of the Hellenic World.

Yatromanolakis, D. and P. Roilos (eds.) 2004. Greek Ritual Poetics, Cambridge, MA and London: Harvard University Press. 